


\section{Online folyóirat}

Szerkesztette: VÁGÁNY Judit Bernadett, PhD - FENYVESI Éva, PhD

Borító: FLOW PR

Kiadja: Budapesti Gazdasági Egyetem, Kereskedelmi, Vendéglátóipari és Idegenforgalmi Kar, Közgazdasági és Üzleti Tudományok Tanszék

Felelős kiadó: FENYVESI Éva, PhD

a Közgazdasági és Üzleti Tudományok Tanszék vezetője

ISSN 2630-886X

2019. 


\title{
NEMZETKÖZI RENDSZER ÉS GEOPOLITIKAI MODELLEK KÖZÉP-EURÓPAI PERSPEKTÍVÁBÓL
}

\author{
INTERNATIONAL SYSTEM AND GEOPOLITICAL \\ MODELS FROM CENTRAL-EUROPEAN VIEWPOINT
}

SZILÁGYI István

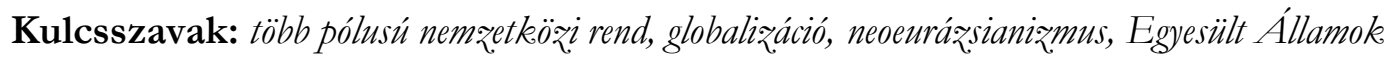
Oroszország, Kina, Új Selyemút Keywords: multipolar international system, globalization, neoeurasianism, US A, Russia, China, new silk road

JEL kód: F50 


\section{ÖSSZEFOGLALÓ}

1991. december 25-én megszünt a Szovjetunió. Mihail Gorbacsov elnöki tisztségröl történö lemondása a szervezett kelet-nyngati konfliktusok lezárulását, a bipoláris világ végét, a nemzetközi viszonyokban bekövetkezó jelentôs változások kezdetét jelentette.

Történelmi értelemben véve rövid ideig egyetlen szuperhatalom, az. Amerikai Egyesült Allamok maradt a színen. Egy évtized elteltével azonban már kibontakoztak egy többpólusú és interdependens nemzetközi rend körvonalai. Növekedett a jelentösége az. Eurázsiai magtérségnek. A neoeurázsianizmus képviselöjeként szinnre lépett a birodalmi státusz visszaszerzése céljával Oroszország. A Kreml vezutése a döntéshozatal során jól basznositja Alexander Dugin geopolitikai elemzéseit. Kina üj szuperbatalomként gyors terjeszkedésbe keqdett és növelte befolyását a világban. A belsó ellentétektöl szabdalt Európai Unió kisérletet tesz megtépázott hatalmi pozícioinak megórzésére.

A jelzett változásokkal párbuzamosan a nemzetköri viszonyok rendszerében megnött a civilizációk, identitások és az új típusú gazdasági-politikai integrációk befolyásoló szerepe. Mindezek a tényezók és folyamatok új térbeli struktúrákat alakitottak ki és jelentös hatást gyakoroltak az egypólusú (atlantista) globalizáció felfogását elutasitó geopolitikai gondolkodás fejlödésére és befolyásolják Közép-és Kelet-Európa nemzetközi viszonyokban játszott szerepét és mozgásterét. A tanulmány a fent vázolt tényezőók elméleti öszefoglalására és szintetizálásra vállalkozile.

\section{SUMMARY}

On 25, December, 1991 the Soviet Union ceased to exist. The resignation of the president, Mihail Gorbacsov meant the end of the eastern-western conflicts and the bipolar world, and it also meant the beginning of the significant changes in the international relations.

In historical sense for a while there was the only one super power, the USA remaining alone in the political battlefield. In a decade the outline of the multipolar and interdependence international system began to crystallize. The signification of the Eurasian Heartland also began to develop. Russia emerged as the representative of neoeurasianism in order to restore.

China as a new super power also started to expand and extend its influence on the world. The European Union with its inner conflicts tries to keep its fragile power position.

Parallel with the above mentioned changes in the system of the international relations the influential role of civilizations, identities and new economical-political integrations have increased.

All these factors and processes have shaped new spatial structures and have significant influence on the geopolitical thinking that rejects the one-poled (Atlantic) idea of globalization and have an effect on the field and role of the Eastern and Central Europe in the international relations. This research paper aims at summarizing and synthetizing the outlined factors.

\section{BEVEZETÉS}

Jelen tanulmány célja a bipoláris világ felbomlását követő negyedszázad nemzetközi viszonyokban és geopolitikai modellekben bekövetkező változásainak elemző bemutatása.

Az írás a legfontosabb és releváns források, dokumentumok, monográfiák és szakirodalom felhasználásával vizsgálja az egy évtizedig fennálló, magányos szuperhatalom, az Amerikai Egyesült Államok dominanciájával leírható egypólusú világrend jellemzőit. Elemzi a 
harmadik évezred beköszöntével kibontakozó többpólusú és interdependens nemzetközi rendszer születési körülményeit és kiépülési folyamatát. Vázolja az állandó változás és újjászerveződés állapotában lévő világrend és a globalizáció bonyolult és sokszínű kapcsolatrendszerét.

Nagy figyelmet fordít a megnövekedett jelentőségű eurázsiai magtérség és az újjászülető orosz birodalmi geopolitika neoeurázsianista aspektusainak vizsgálatára, valamint a szuperhatalmi szerepre és világpolitikai befolyásra törő Kína befolyásának növekedésére és terjeszkedésére.

A tanulmány a jelzett folyamatok, események és változások rendszerszintű, történelmileg objektíven értelmezhető elméleti elemzésére vállalkozik.

\section{Egy magányos szuperhatalom születése és dilemmája}

1991. december 25-én megszűnt a Szovjetunió. Mihail Gorbacsov elnöki tisztségről történő lemondása a szervezett kelet-nyugati konfliktusok lezárulását, a bipoláris világ végét, a nemzetközi viszonyokban bekövetkező jelentős változások kezdetét jelentette.

Egyetlen szuperhatalom, az Amerikai Egyesült Államok maradt a színen. „Az új évezred hajnalán - írja Henry Kissinger - vitathatatlanul Amerika a világ vezető állama, akkora hatalom birtokában, amilyennel a múlt nagy birodalmai közül egyik sem rendelkezett...A 20. század utolsó évtizedében az Egyesült Államok - uralkodó pozíciója okán - a nemzetközi stabilitás nélkülözhetetlen elemévé vált.” (KISSINGER, 2002, p. 9)

Az USA hatalmának alapja öt tényezőn nyugszik. Gazdaságilag a világ folyó árakon és árfolyamokon számított nemzeti össztermékének egynegyedét adja. Ennek nagysága Kína, Japán, Németország és Nagy-Britannia által elő́llított össztermékkel egyenlő. Leghatalmasabb ipari potenciállal rendelkező államként a száz legnagyobb transznacionális vállalat egyharmadának székhelye Amerikában található. Az úgynevezett új gazdaság és a pénztőke növekedési üteme is az Egyesült Államokban a legmagasabb. Technológiai téren az USA vezeti az információs és kommunikációs forradalmat. Katonai területen a csökkenő kiadások ellenére a NATO-val karöltve akció rádiuszát növelni tudta. Amerikáé az egyetlen olyan hadsereg, amely a világ bármely pontján - beleértve az óceánok feletti kontrollt is azonnal bevethető, azonnali beavatkozásra képes. Politikailag jelentős mértékben megerősítette hagyományos befolyását olyan stratégiai jellegű nemzetközi szervezetekben, mint a Valutaalap, a Világbank, a Kereskedelmi Világszervezet. Támogatni tudja országok és térségek demokratizálódási folyamatait és modernizációs törekvéseit. Kulturális síkon az amerikai életmódot és kultúrát szimbolizáló termékek, intézmények, értékek, produktumok a föld minden pontjára eljutottak, globális jelleget öltöttek.

E tények ellenére Kissinger arra hívja fel a figyelmet, hogy jóllehet „A hidegháború vége megteremtette az egyesek által egypólusú, vagy „egy szuperhatalom” világot. Az Egyesült Államok azonban most sincs jobb helyzetben ahhoz, hogy egymaga döntsön a világ ügyeiről, mint a hidegháború kezdetén. Amerika nagyobb befolyással bír, mint tíz évvel ezelőtt, azonban paradox módon, a hatalom is több központ között oszlik el. Ilyen módon Amerika képessége, hogy saját kedve szerint alakítsa a rajta kívül eső világot, valójában csökkent." 
(KISSINGER, 2008, p. 809-810). Kissinger szerint az Egyesült Államok mindenekelőtt a wilsonizmus idealizmusa és a Theodor Roosevelt által képviselt és megalapozott reálpolitika elveinek és gyakorlatának összehangolásával, az ország nemzeti érdekeinek meghatározásával szilárdíthatná meg, s tehetné hosszú távon fenntarthatóvá hegemóniáját.

A nagy sakktábla, valamint Stratégiai vízió címú könyveiben Zbigniew Brzezinski a világ elsó globális hatalmának nevezi az Egyesült Államokat. Ezt részben a történelmi körülményeknek, részben pedig az USA belső fejlődéséből fakadó folyamatok következményének tekinti. „Vetélytársának összeomlása különleges helyzetet eredményezett az Egyesült Államok számára. - olvashatjuk Brzezinski elemzését. Egyszerre vált az első és egyben az egyetlen valóban globális hatalommá. Amerika világelsősége bizonyos tekintetben mégis emlékeztet a korábbi birodalmakéra, még ha azok befolyása csak egy-egy régióra korlátozódott is... Akárcsak a múltbeli birodalmak esetében, az amerikai „birodalmi” erő is nagyrészt a kiváló szervezésből, a hatalmas gazdasági és technológiai erőforrások katonai célokra történő azonnali alkalmazásának képességéből, az amerikai életforma nehezen megfogható, de mégis jelentős kulturális vonzásából, és az amerikai társadalmi és politikai elit hamisítatlan dinamizmusából, és eredendő versenyképességéből fakad.” (BRZEZINSKI, 1999, p. 17-18) Az amerikai globális rendszer legfőbb jellegzetességét, korábbi birodalmaktól és hatalmi képződményektől alapvetően eltérő jellegzetességét Brzezinski szerint az adja, hogy „Bár Amerika nemzetközi elsősége óhatatlanul felidéz korábbi birodalmi rendszerekkel való hasonlatosságokat, a különbségek fontosabbak, s túlmutatnak a területiség kérdésén. Amerika világméretû hatalmát egy olyan jellegzetesen amerikai típusú globális rendszeren keresztül gyakorolja, amely tükrözi az amerikai tapasztalatot. Ennek lényegi eleme mind az. amerikai társadalom, mind az amerikai politikai rendszuer plurális jellege” (BRZEZINSKI, 1999, p. 36)

Az Egyesült Államok vezette, nemzetközi kooperációk, integrációk és koalíciók hálózatára épülő rendszernek azonban nagy kihívásokkal kell szembenéznie. E nagy kihívás megtestesítői elsősorban Eurázsia Sir Halford Mackinder által kulcsövezetnek és magterületnek nevezett térsége, valamint az azt körülölelő spykmani peremterület stratégiai pozícióban lévő országai. (SZILÁGYI, 2018, p. 52-68 és 90-98). „Amerika számára a fő geopolitikai tét Eurázsia. Fél évezreden keresztül a világot olyan eurázsiai hatalmak és népek uralták, amelyek egymással harcoltak a regionális uralomért, miközben a globális hatalom megszerzésére törekedtek. Jelenleg egy nem eurázsiai hatalom tölt be vezetô szerepet Eurázsiában, és Amerika globális elsősége közvetlenül attól függ, hogy meddig és milyen hatékonyan tudja fenntartani dominanciáját ezen a kontinensen. Ez a helyzet nyilván nem tart örökké. De az, hogy meddig tart és mi követi, rendkívül fontos nemcsak Amerika boldogulását illetően, hanem általában a nemzetközi béke szempontjából is. Az első és egyetlen globális hatalom hirtelen felbukkanása a világban olyan helyzetet eredményezett, amelyben a vezető szerep hasonlóan gyors megszűnése - akár Amerika visszahúzódása, akár egy sikeres vetélytárs hirtelen megjelenése miatt - súlyos nemzetközi bizonytalanságot idézne elő, sôt világméretű anarchiához vezetne.” (BRZEZINSKI, 1999, p. 44) 
A mackinderi elméleti alapvetésen és sajátos kontinuitást megtestesítő szellemi örökségen túl mi adja Eurázsia történelmi és geopolitikai jelentőségét? Mindenekelőtt kiterjedése és földrajzi elhelyezkedése. A geopolitikai szempontból tengelyszerepet betöltő Eurázsia a világ legnagyobb földrésze. Az Eurázsia fölötti ellenőrzés ezért az Afrika feletti uralmat is jelenti. Óceániát és a nyugati féltekét pedig ehhez képest marginális helyzetben hozza.

Eurázsia nem csupán egyedülállóan kedvező földrajzi-stratégiai pozíciójának köszönheti geopolitikai fontosságát. E makrorégióban él a föld lakosságának 75\%-a, itt állítják elő a világ bruttó nemzeti össztermékének 60\%-át, és itt áll rendelkezésre a világ ismert energiatartalékának 75\%-a. A huszonegyedik század első felében e térségben található a dinamikusan fejlődő, nagyhatalmi és regionális hatalmi befolyásra és szerepre törő államok többsége: Kína, India, Japán, Indonézia, Törökország, Dél-Korea, Oroszország, Irán, Franciaország, Németország stb.

Az eurázsiai sakktábla különböző mezőin az amerikai hegemónia megtartása, fenntartása, érvényesítése és alakulása szempontjából Brzezinski szerint öt geostratégiai játékos (Németország, Franciaország, Oroszország, India, Kína), több geopolitikai pillér (Ukrajna, Törökország, Azerbajdzsán, Irán és Korea), valamint potenciális geopolitikai játékos (NagyBritannia, Üzbegisztán, Kazahsztán, Pakisztán, Thaiföld, Tajvan, Japán és Indonézia) tevékenykedik.

„Az az állam tekinthető aktív geostratégiai játékosnak - olvashatjuk a volt nemzetbiztonsági főtanácsadó sorait - , amely rendelkezik a kellő erôvel és nemzeti akarattal ahhoz, hogy hatalmát és befolyását határain túl felhasználja az éppen adott geopolitikai helyzet - Amerika érdekeit is befolyásoló mértékủ megváltoztatására.....A geopolitikai pillérek azok az államok, amelyeknek fontossága nem hatalmukból vagy becsvágyukból fakad, hanem stratégiai elhelyezkedésükből, illetve abból, hogy esetlegesen kiszolgáltatott helyzetük hogyan hat a geostratégiai játékosok viselkedésre.” (BRZEZINSKI, 1999, p. 57)

Az USA-nak a hosszú távú amerikai hegemónia intézményesítése céljából differenciált, rugalmas, szelektív, a történelmi körülményekhez alkalmazkodó stratégiát és szövetségi politikát kell kidolgoznia és követnie. A különbözó civilizációk találkozási, érintkezési pontjának, együttélésének, egymás mellett létezésének és összecsapása zónájának is tekinthetó Eurázsia ugyanis a világ közepe. Mackinder megfogalmazását kölcsönvéve tehát: aki ellenörzi Eurázsiát, uralja a világot. Brzezinski ezért tekinti alapvető jelentôségűnek azt a feltételt, hogy „időközben ne jöjjön létre olyan eurázsiai hatalom, amelyik uralkodó tényező lehet ott, és kihívást jelenthet Amerika számára," (BRZEZINSKI, 1999, p. 8) és emellett azt is, hogy egyetlen hatalom, vagy hatalmi koalíció se vonhassa uralma alá az Eurázsiai magterületet. Az Egyesült Államoknak tehát az elkövetkezendő évtizedekben kettős szerepet kell játszania egy szilárd globális rend kialakítása, megteremtése és biztosítása érdekében, - hangsúlyozza. „... napjaink világát mind kevésbé tudja egyetlen hatalom dominálni, még akkor is, ha katonilag olyan erôs és politikailag olyan befolyásos, mint az Amerikai Egyesült Államok. Mivel Amerika még nem Róma, és Kína még nem Amerika Bizánca, egy szilárd globális rend végső soron azon múlik, hogy Amerika képes-e megújítani magát és bölcsen cselekedni, mint egy új életre kelt 
Nyugat támogatója és garantálója, és mint egy felemelkedő új Kelet egyensúlytermetóje és megbékitöje.” (BRZEZINSKI, 2013, p. 263)

Brzezinski koncepciójával rokon vonásokat mutat Paul Kennedy és munkatársai által felvázolt tengely államok elmélete. Az 1996-ban született tanulmányban kifejtettek szerint öt évvel a Szovjetunió összeomlása után az Egyesült Államoknak még nem sikerült kialakítania külpolitikája általános irányvonalát. A szerzőhármas azt állítja, hogy az USA biztonsága egy anarchikus, és decentralizált világban már nem a kommunizmus fennmaradásától, vagy bukásától függ. A kihívások nagy száma és intenzitása ugyanakkor átfogó stratégia kidolgozását teszi szükségessé. Ebben a helyzetben az USA-nak hosszú távon érvényes és stabil prioritás és célrendszer meghatározására van szüksége. Vitán felül áll, hogy kiemelkedő jelentősége van az Európához, a Japánhoz, Oroszországhoz és Kínához fűződő viszonynak. Az Egyesült Államok nemzeti érdekei szempontjából azonban fontosnak tekinthetôk a világ más térségeinek, különösen a fejlődő országoknak a stabilitása. „Az USA-nak koncentrálnia kell erőfeszítéseit az országok egy olyan kis csoportjának támogatására is, amelyek helyzete bizonytalan, és amelyek jövője mélyen érinti az Egyesült Államokat, és amelyek az USA-t körülvevő régiókban találhatók: ezek a tengelyállamok." (CHASE - HIL - KENNEDY, 1996, p. 36)

E fogalom kialakítása is Mackinder nevéhez füződik. A brit földrajztudós a kifejezést olyan országok esetében alkalmazta, amelyek nem csupán meghatározták egy régió sorsát, hanem amelyek a nemzetközi rendszer stabilitása szempontjából is jelentőséggel bírtak. Ennek az államtípusnak klasszikus példáját jelentette a XIX. században a kelet kulcsaként emlegetett Törökország. Az észak-amerikai politikai szótárban a huszadik század időszakában honosodott meg a fogalom. Dwight Eisenhower, Dean Acheson, Richard Nixon és Henry Kissinger egyaránt a fentebb kifejtett értelemben használták. Az Egyesült Államok érdekei szempontjából fontos, de bizonyos szempontból sebezhető országok tartoztak e körbe. A hidegháború időszakában a kommunizmus által veszélyeztetett olyan államokat értettek a fogalom alatt, amelyek a dominósor gyenge láncszemét alkották. Bukásuk ugyanakkor szomszédjaikat is magával rántotta volna, ezért „e kosárban megbúvó romlott almák” kiemelése (országok megmentése, megtartása) az Egyesült Államok alapvető érdeke volt. Természetesen a fogalmat adaptálni kellett a hidegháború korszakának lezárulása utáni korszak körülményeihez. Az Amerikai Egyesült Államok stratégiai érdekei szempontjából tengely államoknak tekinthető országokra napjainkban már elsősorban nem külső, hanem a belső rendezetlenségből fakadó fenyegetettségek leselkednek. Ilyennek tekinthetôk a túlnépesedésből, a migrációs hullám felerősödéséből, az etnikai és nemzeti konfliktusokból, az állam gyengeségéből, a maffiózó, terrorista és szeparatista erők tevékenységéből, valamint a gazdasági-társadalmi válságból eredő veszélyek. Ezeket az országokat az Egyesült Államoknak, mint stratégiai szövetségest hathatós támogatásban kell részesítenie. A szerzőhármas szerint az elemzés elkészülése időpontjában kilenc, különböző perspektívával rendelkező ország - Mexikó, Brazília, Algéria, Egyiptom, a Dél-afrikai Köztársaság, Törökország, India, Pakisztán és Indonézia - sorolható a tengelyállamok csoportjába. 
Zbigniew Brzezinski és Paul Kennedy fentebb kifejtett koncepciójával rokon felfogást jelent és ahhoz hasonló vonásokat mutat Saul Bernard Cohen 2009-ben megjelent Geopolitics. The Geography of International Relations (Geopolitika. A nemzetközi viszonyok földrajza) címú monográfiájában a XXI. század elejének négy geostratégiai övezetéról, birodalmáról (realm) készített elemzése. Cohen Kereskedelem-függó tengeri birodalomról, Eurázsiai kontinentális övezetról, Kelet-Ássiai birodalomról és az India által vezetett, befolyásolt, a Delhi által uralt, a Delhi hegemóniája számára megelőlegezett Indiai-óceáni övezetröl beszél. A geostratégiai birodalmakon, nagyrégiókon belül geopolitikai nagytérségek, geopolitikai régiók, ütköző övezetek (Shatterbelts), egyelőre pontosan nem definiálható státuszú zónák (Compression Zone) és hídrégiók (Gateways) találhatók. A geostratégiai és geopolitikai régiókhoz vezető államok, nagyhatalmak tartoznak. A huszonegyedik század első negyedérôl Saul Bernard Cohen által készített geopolitikai elemzés hét nagyhatalmat, hatalmi központot - az Egyesült Államok, Brazília, az Európai Unió, Oroszország, India, Kína, Japán - nevesít (1. ábra).

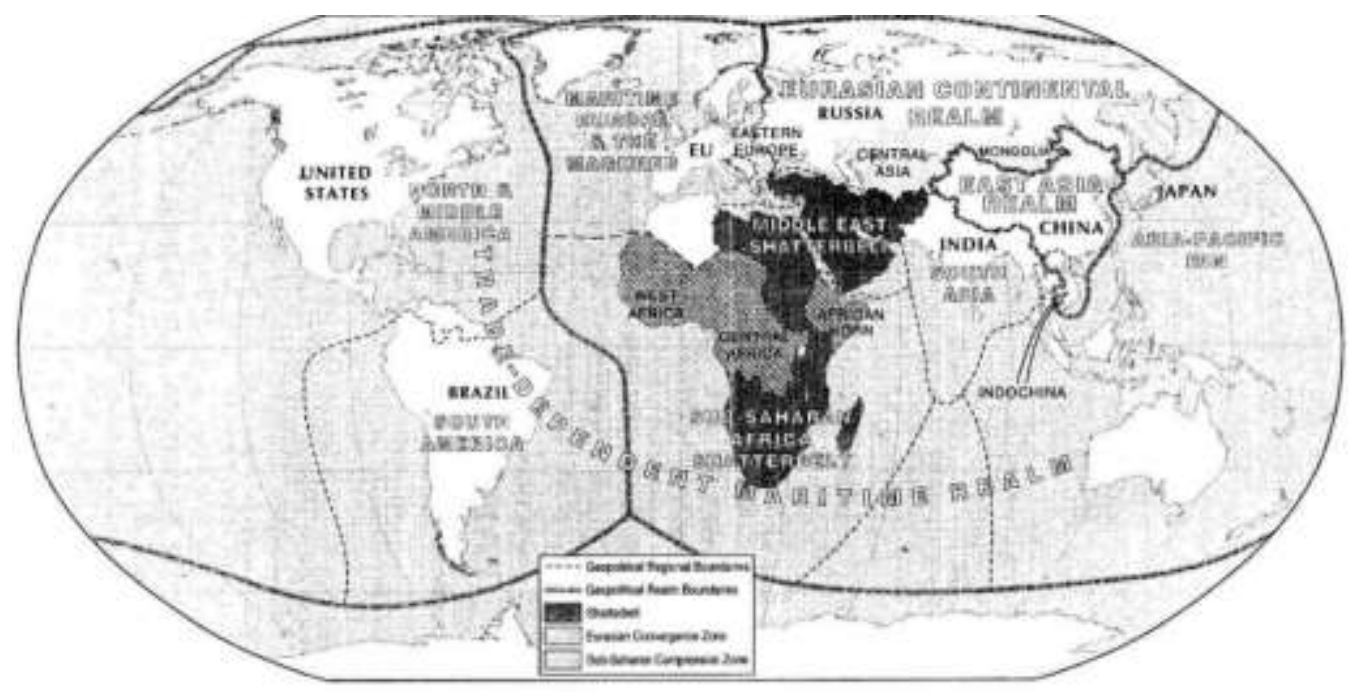

1. ábra. A világ a huszonegyedik század kezdetén

Forrás: COHEN, S. B. (2009): Geopolitics. The Geography of International Relations. Rowman \& Littlefield Publishers, Inc. New York, p. 423.

Egy korábbi, avagy inkább más típusú állapotot rögzítő szellemi térképen Cohen a nagyhatalmak és a regionális hatalmak listáját tárja elénk. A felsorolt és említett nagyhatalmak körét Mexikóval, Venezuelával, Argentínával, Algériával, Nigériával, a Dél-Afrikai Köztársasággal, Egyiptommal, Izraellel, Szaúd-Arábiával, Iránnal, Pakisztánnal, Törökországgal, Thaifölddel, Indonéziával, Vietnammal, Tajvannal, Dél-Koreával és Ausztráliával egészíti ki. Ezeknek az országoknak egy részére akár a Brzezinski által bevezetett geostratégiai játékos, illetve geopolitikai pillér, esetleg a potenciális geopolitikai pillér kategóriáját is alkalmazhatnánk, de a Paul Kennedy-féle tengely államok csoportjába is sorolhatnánk őket. 
Hasonlóan differenciált megközelítéssel találkozunk José Alberto Loureiro dos Santosnak Eurázsiával kapcsolatban a globális hatalom térbeli szigeteiről készített elemzésében is. A portugál szerzô a globális hatalom térbeli szigeteinek ötfokozatú rendszerét vázolta fel. (LOUREIRO DOS SANTOS, 2008) A mackinderi és a spykmani elmélet alapul vételével megkülönbözteti a globális hatalom két szigetét (Ilhas de Poder Global), az Egyesült Államokat és Kínát. A kvázi globális hatalmak (Quase-Ilhas de Poder Global) közé Oroszországot, Indiát és Brazíliát sorolja. A félig globális hatalmi szigetek (Semi-Ilhas de Poder Global) sorába az Európai Uniót, a Fekete-tenger, a Kaszpi-tenger, a Kaukázus-hegység, a Vörös-tenger, az Arab-félsziget, Irán, Törökország alkotta Eurázsia déli részét sorolja. A globális hatalmi együttes negyedik szintjét, a globális hatalom kis szigeteit (Ilhéus de Poder Global) a nagy lehetőségekkel rendelkező olyan államok alkotják, mint Kanada, Nagy-Britannia, Franciaország, Németország és Japán. Az ötödik szintet a globális hatalom kvázi kis szigetei (Quase-Ilhéus de Poder Global) országai képviselik. Ezek sorába tartozónak véli Loureiro dos Santos többek között Venezuelát, Ausztráliát, a Dél-Afrikai Köztársaságot, Iránt, Törökországot, Szaúd-Arábiát stb. Louriero dos Santos vitatható geopolitikai világképe Saul Bernard Cohentől eltérően a huszonegyedik század első évtizedében nem ruházza fel a globális jelentőségű geostratégiai régió pozíciójával az eurázsiai kontinentális magterületet és az Indiai-óceáni övezetet. Cohenhez hasonlóan a geostratégiai nagyhatalmak, azaz a kvázi globális hatalmak közé sorolja az eurázsiai kontinentális magterületet megtestesítő Oroszországot, az Indiai-óceáni világot megjelenítő Indiát és Braziliát (ez utóbbi országot Cohen is nagyhatalomnak tekintette), az Európai Uniót és a nehezen meghatározható és meglehetősen heterogén Eurázsia déli részének nevezett övezetet. A problémát a jelzett esetben a két szerző által nem azonos módon alkalmazott és nem azonos tartalommal rendelkező, ezért nem pontosan összemérhető geopolitikai skála jelenti. Ha mindehhez még azt is hozzávesszük, hogy Henry Kissinger: Korszakváltás az amerikai külpolitikában? (KISSINGER, 2002) címú könyvében a huszonegyedik században az Egyesült Államok előtt álló legfontosabb kihívásnak négy nemzetközi rendszerrel - Nyugat-Európával, az ázsiai nagyhatalmakkal, Közel-Kelettel és Afrikával - való kapcsolatot jelenti, akkor láthatjuk igazán, hogy a geopolitikai gondolkodás, a nemzetközi viszonyok és a geopolitika elmélete mekkora kihívásokkal néz szembe korunkban (2. ábra). 


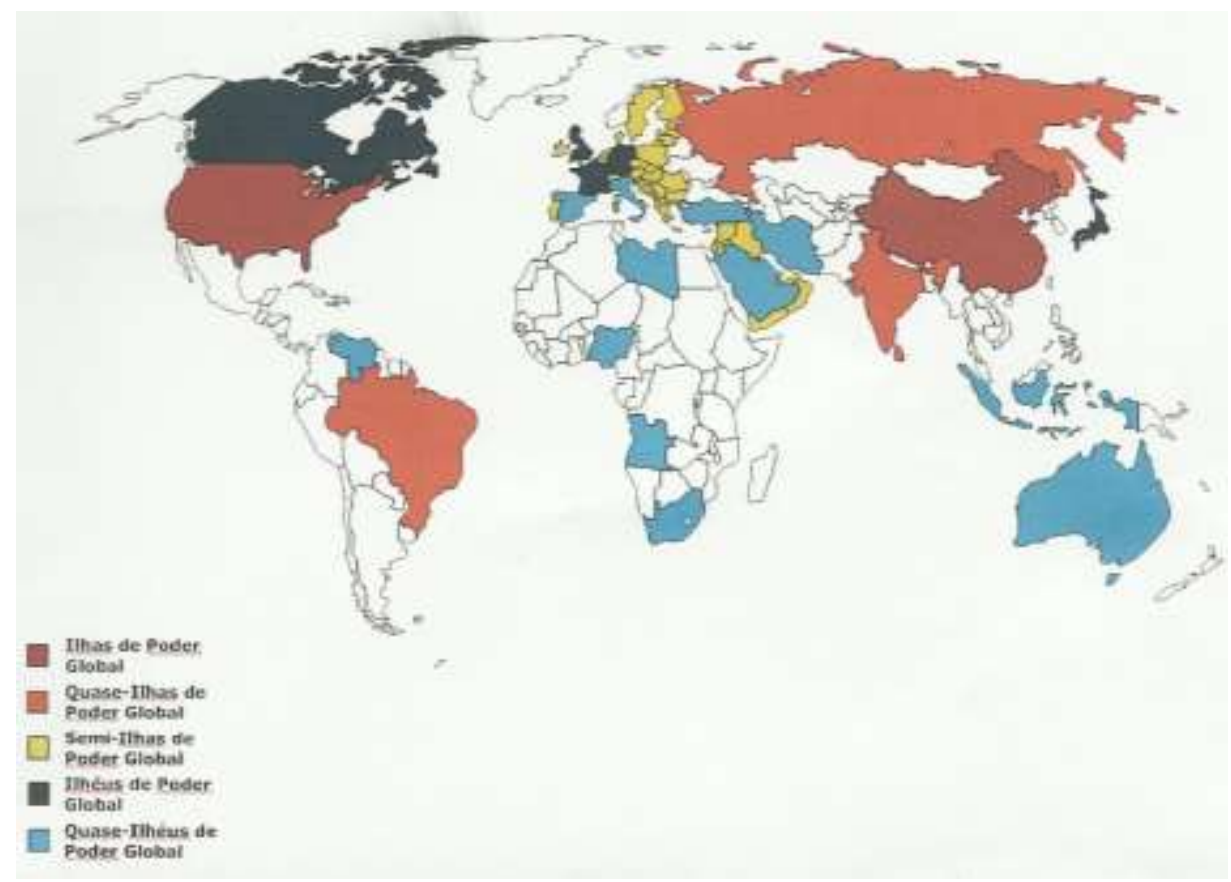

2. ábra. A globális hatalom térbeli szigetei

Forrás: LOUREIRO DOS SANTOS, J. A. (2008): O Coração da Eurásia contra o resto do mundo. Ensaio geopolítico e relações internacionais. Comunicação Academia de Ciêcias de Lisboa do socio correspondente. Lisboa, p.22.

A fenti elemzések és a történelmi tények alapján leszögezhető, hogy a buszonegyedik század kezdetén számos tényezó, játékos és nemzetközi szereplö korlátozta és korlátozza a többközpontú, az. értékhomogenitás irányába elmozduló nemzetköz̨i rendszerben és társadalomban a magányos szuperhatalom mozgásterét és lehetöségeit, megteremtve ezáltal egy többpólusú, interdependens nemzetközi rend kiépülésének és létrejöttének feltételeit. Az eddigiekböl az is egyértelmüvé válik, hogy Európa (és az Európai Unió) szerepe, relativ súlya és befolyása csökkeen a világban. Ezzel szemben nö Kina, Oroszország és az Eurázsiai térség jelentősége. Bruno Maçães az új világrend alakulása és formálódása kapcsán Eurázsia megkerülhetelenségéről, Eurázsia Hajnaláról ír. (MAÇÃES, 2018)

A nemzetközi rendszer alakulását és fejlődését, a különböző típusú szereplők hatalmi vetélkedését és mozgásterét, valamint a geopolitikai gondolkodás evolúcióját azonban nagymértékben befolyásolják és meghatározzák a globalizációs folyamatok és a globális környezet új kihívásai is.

\section{Nemzetközi rendszer és globalizáció}

A huszonegyedik század nem csupán a nagyhatalmak közötti vetélkedésnek, hanem a globalizációnak, a különböző értékeket, értékrendszereket képviselő kultúrák, civilizációk, identitások és identitásformák találkozásának, a külkapcsolatok társadalmasodásának, a multikulturális jelleget öltő public diplomacy előtérbe kerülésének is a korszaka. A globalizáció és a civilizációk, kultúrák, külpolitikát alakító befolyása, szerepe nem ismeretlen 
tényezője a történelemnek. Joaquim Aguiar (AGUIAR, 2000), Immanuel Wallernstein (WALLERNSTEIN, 1983) felfogásához hasonlóan a XVI-XVII. század nagy európai expanziójához köti a globalizáció első hullámát. A termékek forgalma, az áruk cseréje már az egységes világgazdasági rendszer kialakulásának kezdeti szakaszában átlépte a nemzeti és az európai határokat, s a nemzetköziesedés és az egyetemes érintkezés folyamata révén összekapcsolta a regionalizáció és a lokalizáció, valamint a különböző helyi kultúrák és civilizációk szféráját.

A tizenkilencedik század második felében, a huszadik század első két évtizedében beinduló újabb globalizációs hullám már a tőkék körforgásának és az amerikai világhegemónia megerősödésének jegyében fogant. „A XX. századtól a XXI. századhoz vezető jelenlegi globalizáció azonban az előző kettő magasabb fokú szintéziseként állandó változások, mozgások hálózataként, termékek és tôkék szakadatlan körforgásaként jelenik meg."(AGUIAR, 2000, p. 60.)- olvashatjuk Joaquim Aguiar fejtegetéseit.A globalizáció történelmi folyamatának (SZILÁGYI, 2006, p. 277-292) következményeként és részeként, az egységes világgazdasági rendszer létrejöttének eredményeként a nemzetközi kereskedelmi kapcsolatok szférájában megvalósult az országok egyre növekvő gazdasági és politikai összekapcsolódása, internacionalizációja. Ezzel párhuzamosan a nemzetek feletti multinacionális társaságok által szervezett és irányított termelés révén kibontakozott és felerősödött a transz̨acionalizáció folyamata. Globális jelleget öltött a gazdaság, a kultúra, a fogyasztás, a mindennapi élet, a nemzetek és a társadalmak közötti érintkezés. Univerzális modellekben rögzültek a kormányzati formák és politikai rendszerek. Hálózatok és áramlatok formájában (WHOSE EUROPE?, 1999; CASTELLS, 2005) szerveződik és működik a turbulenssé (ROSENAU, 1990) vált és sokszereplős nemzetközi rendszer. A „Governance without Government” állapota kiegészül az új regionalizmus többszintű kormányzati struktúráival. A globális problémák tudatosulása „globális tudat” kialakulásához vezetett. A hagyományos (geo)politikai gondolkodás ugyanakkor már nem képes válaszolni a tér-idő összesűrűsödött koordináta rendszerében végbemenő mozgásokra. Átalakult és eltűnt az állami szereplők kizárólagosságán és mindenhatóságán alapuló westfáliai típusú nemzetközi rendszer. (RAI NAYAR, 2005)

A jelzett strukturális változások az állami szférát is elérik. A területi elv alapján szervezett főhatalomnak alkalmazkodnia kell a globalizáció, az internacionalizáció és a transznacionalizáció viszonyaihoz. Az internacionalizáció szuverén államok viszonyával összefüggő folyamat, a globalizáció szupranacionális jelenség. Nem kötődik semmiféle területi vagy más alapon szerveződő globális kormány létéhez, s nem tételez fel államok közti magasabb rendû politikai kapcsolatot sem. A globalizáció és az internacionalizáció egymás mellett és egyidejüleg együtt is létezhet. Ez azonban nem feltétlenül jelenti ezen intézményesült formát öltő tendenciák és mozgástörvények közötti együttműködést. A tények az állam egyre csökkenő szerepét mutatják a globális folyamatokban. Nemzetközi színtéren „a többszintű kormányzás komplex rendszerében - olvashatjuk David Held fejtegetéseit - a szuverenitást felváltotta, a közhatalommal osztozó, egyben a közhatalommal felruházott különböző szintű közszereplők és ügynökségek által befolyásolt megosztott 
szuverenitás. A területi közhatalom kizárólagos formájára épülő egységes szuverenitás fogalom westfáliai koncepcióját a közhatalom és a tekintély gyakorlásában osztozó új szuverenitás felfogás helyettesíti.” (HELD, 2000, p. 163)

Az állam (nemzetállam) megítélésünk szerint ennek ellenére nélkülözhetetlen szereplője maradt és marad a nemzetközi viszonyoknak. Nem csupán a nemzetközi jogi jogrend és az alkotmányjogi szabályozás szükségszerűsége, hanem a szubszidiaritás elvében megtestesülő társadalomfilozófia és gyakorlat miatt is. Az államnak, bár megváltozott formában, de történelmi rendeltetése van. Az állam az adott területen élő népesség viszonylatában a társadalmi együttélés általános feltételeinek, valamint a demokratikus legitimáció belsó feltételrendszerének biztosítására hivatott. Szerepének, működési formáinak és új típusú intézményesülésének megnyilvánulásai természetesen nem jelentik a nemzetközi viszonyok hagyományos formáinak favorizálását. Az állam azonban megtartotta a globalitás új szereplői legitim becsatornázásának a funkcióját. „Ezért a globalitás korának kihívása a megosztott szuverenitás jegyében az állam katalizátor és szabályozó szerepének a közös érdekek és a közérdek megvédése érdekében történő újradefiniálásában áll.” (ALDEANUEVA, 2001, p. 226)

A kulturális tényezők külpolitikát alakító és külpolitikát meghatározó szerepét valló konstruktivista megközelítésmód sem tekinthet el tehát a tér és a hely identitást, kultúrát és civilizációt, valamint territoriális történelmet formáló szerepének tudomásul vételétől. (NOGÉ FONTE - VICENTE RUFÍ, 2001). A területi elv meghaladása alapján álló új regionalizmus-típusú integrációs tendenciákkal és szervező́désekkel párhuzamosan felerősödtek ugyanakkor az új államok és politikai entitások létrejöttét eredményező lokális terekhez, földrajzi helyekhez és konkrét történelmi szituációkhoz kapcsolódó kulturális különbözőségeken és másságon alapuló, a migráció és a multikulturalizmus által befolyásolt dezintegrációs folyamatok.

A Cybertérrel és az információs szférával kiegészült új térbeli integrációs struktúra jön létre, amely a hagyományos megközelítést alapul véve a következőképpen ábrázolható és jellemezhető (3. ábra). 


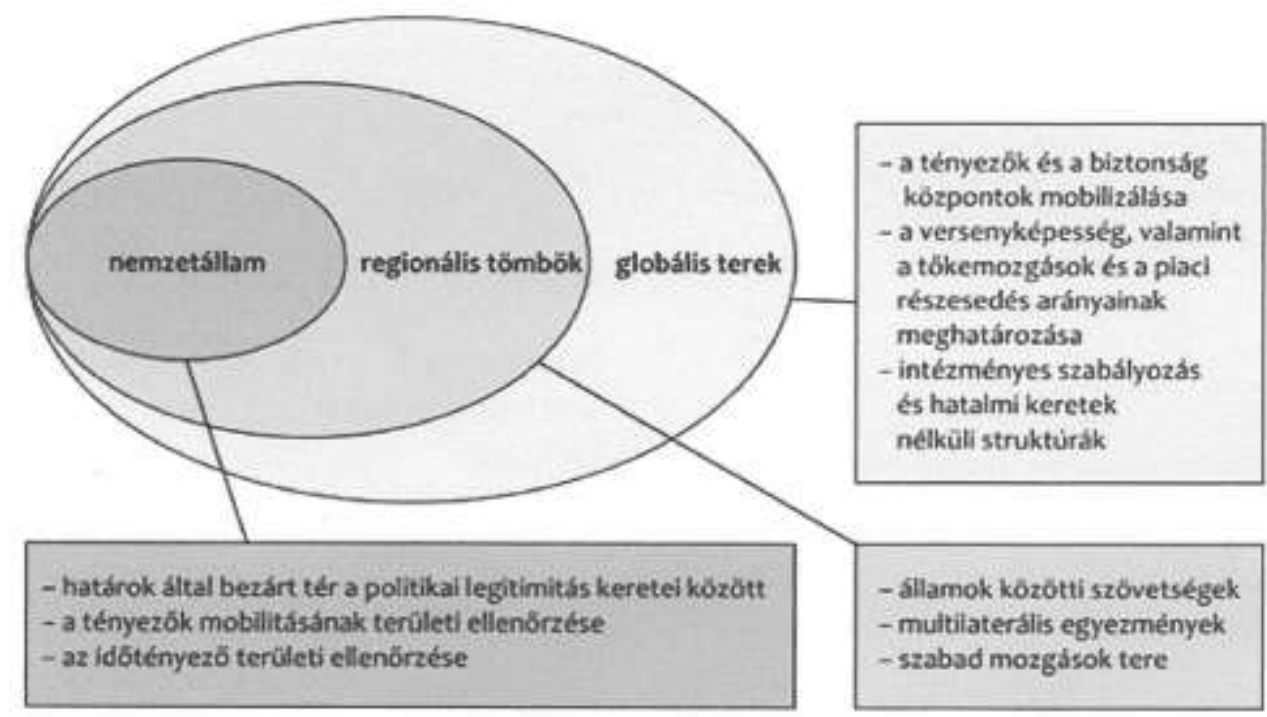

\section{3. ábra. A globális korszak új térbeli szerkezete}

Forrás: Saját szerkesztés

A posztnemzeti globalizáció, a posztnemzeti politika és külpolitika korszakában a hatalom területi alapját a hálózatok, folyamatok, áramlatok rendszere váltja fel. Ez képezi a (társadalmi) tudás legfontosabb forrását. „...A globalizáció és az európai integráció folyamata viszonylagossá tette az önazonosságokat, behatolt e zárt rendszerekbe és felbomlasztotta azokat. Társadalmon túli és területen kívüli diszkurzív tereket és hálózatokat alkotott a tér-idő végú létezés határán." (AXFORD - HUGGINS, 1999, p. 176). Ez a körülmény jelentős mértékben megváltoztatja és módosítja a szuverenitásról, azaz egy adott területen élő népesség fölött állami szervek útján gyakorolt döntési jogosultságról alkotott felfogást.

A kollektív létezésnek azonban a huszonegyedik században is különböző módjai és formái vannak. Európában, akárcsak a világ más részein a határok és az etnikai-területi, civilizációs különbségek továbbra is fontos tényezőnek tekinthetôk. Ezért a harmadik globalizációs hullám időszakában sem feledkezhetünk meg az integráció-dezintegráció sajátos dialektikájának, változó viszonyának alakulásáról, s a nemzeti-kulturális tényezők identitásmegőrző és értékképző funkciójának fontosságáról.

A nemzeti érdekek érvényesítésében és megjelenítésében egyre nagyobb szerephez jutnak a nem állami, a nem kormányzati társadalmi szereplők, intézmények, szervezetek és mozgalmak. Megnő a kultúrák, a civilizációk, a virtuális és valóságos regionális és szubregionális hálózatok és hálózatközi viszonyok és szerveződések szerepe.

A globális világ posztnacionális politikája ugyanakkor fenntartja a posztmodern áramlatok terét (space of flows) éppen úgy, mint a modernitás viszonyaihoz köthetô belyek terïletét, területi teret (space of places). Annak ellenére, hogy a hálózatok és az áramlatok a megjelenő információs társadalomban és új gazdaságban a politika belső lényegéhez tartoznak, s változékonyabbak, 
rugalmasabbak a hagyományos kormányzati intézményeknél, nem képesek (és talán nem is akarják és nem is tudják) megszüntetni és kiszorítani a társadalmi élet különböző szintjein és színterein megnyilvánuló nemzeti és kulturális önállóságot és identitást.

„A hidegháború utáni világban, a világtörténelem folyamán először, a világpolitika sokpólusúvá és sokcivilizációjúvá vált......Az emberek a politikát nemcsak arra használják, hogy előmozdítsák érdekeiket, hanem arra is, hogy meghatározzák identitásukat. Csak akkor tudjuk, kik vagyunk, ha azt is tudjuk, kik nem vagyunk, sőt gyakorta csak akkor, ha azt is tudjuk, kik ellen vagyunk.," - írja Samuel Huntington civilizációk összecsapásáról és jellemzéséről kiadott és magyar nyelven is megjelent híres múvében. (HUNTINGTON, 1998, p. 16-17) A szerző ugyanakkor az időtálló, történelmi elemzéseken alapuló modellek és új gondolkodási keretet képező paradigmák fontosságára hívja fel a figyelmet. Elutasítja a történelem végéről szóló egyetlen világ: eufória és harmónia, a Két világ: mi és őke, továbbá a Körülbelül 184 állam „realista” felfogását és a Teljes káosz-teóriáját egyaránt. Henry Kissingerrel ért egyet, aki szerint „A XXI. század nemzetközi rendszerét látszólagos ellentmondás fogja jellemezni; egyfelől a töredezés, a fragmentáció, másfelől a fokozott egységesedés. Az államok közötti kapcsolatok szintjén az új rend inkább hasonlít majd a XVIII-XIX. századi európai államok rendszeréhez, mint a hidegháború merev gyakorlatához. Legalább hat nagyhatalmat foglal majd magában - az Egyesült Államokat, Európát, Kínát, Japánt, Oroszországot és valószínúleg Indiát -, valamint a közepes nagyságú és kisebb országok sokaságát.” (KISSINGER, 2008, p. 16). Huntington szerint a huszonegyedik századi törésvonalak azonban a különböző civilizációkat megtestesítő hatalmak, hatalmi formációk, államcsoportok között húzódnak. A szerző művében hét vagy nyolc civilizációt különböztet meg: a nyugatit, a latin-amerikait, az afrikait, az iszlámot, a kínait, a hindut, az ortodoxot, a buddhistát és a japánt. Az első kettő között jelentős hasonlóságok fedezhetők fel, mivel a latin-amerikai az európai civilizáció leszármazottja. Ennek ellenére saját identitással rendelkezik és mind az Egyesült Államok, mind pedig Európa által képviselt úttól jelentős mértékben különbözik (4. ábra). 


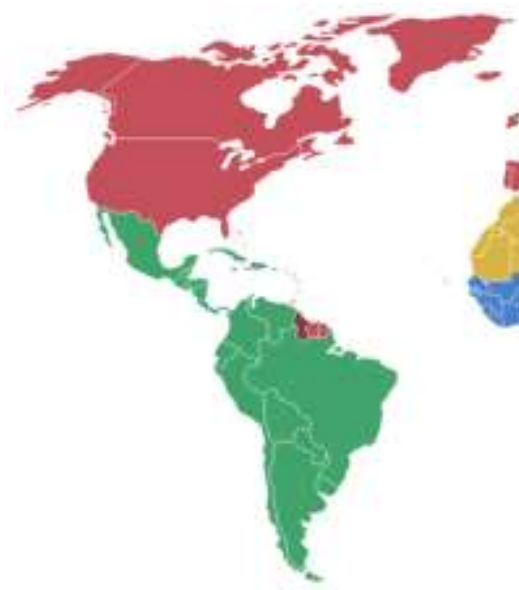

Nyugati kereszténység

Ortodox világ

Latin-Amerika

Buddhista övezet

Hindu civilizáció

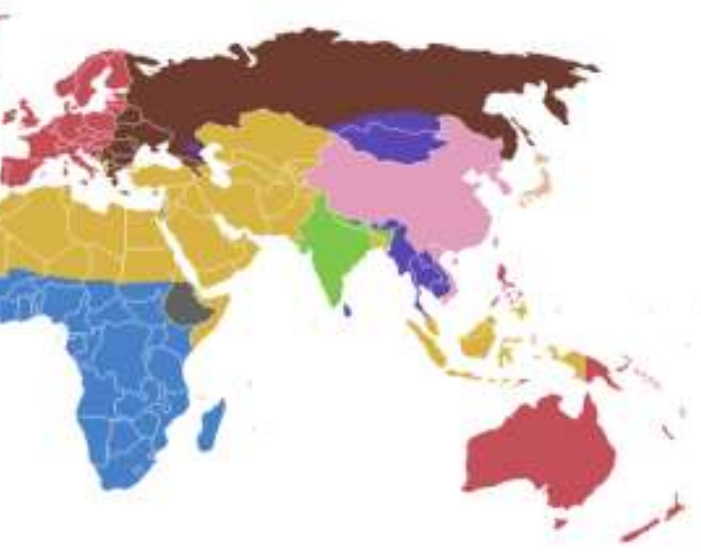

Iszlám világ

kínai civilizáció

Sub-Saharai Afrika

Japán

\section{4. ábra. Főbb civilizációk a huszonegyedik században}

Forrás:http:/ / en.wikipedia.org/wiki/File:Clash of Civilizations map.png (Letöltve: 2019. július 1.)

Huntington elutasítja a modernizáció és a nyugatiasodás (westernizáció) közötti azonosságtételt. Megítélése szerint a modernizáció semmilyen értelemben nem vezet egyetemes civilizáció kialakulásához, illetve a nem nyugati társadalmak nyugatiasodásához. Éppen ellenkezőleg! A civilizációk közötti erőegyensúly módosul. A Nyugat ereje és relatív befolyása csökken, hanyatlik, miközben ezen belül nő az Egyesült Államok által képviselt kulturális minta súlya. Huntington Brzezinskihez, Paul Kennedyhez - és kisebb részben Kissingerhez - hasonlóan az eurázsiai kontinensre figyel. Az ázsiai civilizációk gazdasági, politikai, katonai, demográfiai erejének növekedését, és ennek a körülménynek, valamint a civilizációk közötti harcnak a nemzetközi viszonyokra gyakorolt destabilizáló hatását prognosztizálja.

„A Nyugatot saját egyetemesítő törekvései - vélekedik Huntington - mindinkább konfliktusokba sodorják más civilizációkkal, leginkább az iszlámmal és Kínával...ezért...Az elkövetkezendő időszakban a világ békéjét leginkább a civilizációk összecsapása fenyegeti, és a világháború veszélyét egyedül a civilizációk segítségével létrehozott nemzetközi rend háríthatja el." (HUNTINGTON, 1998, p. 557)

Nyilvánvaló tény, hogy a hidegháború befejeződése után a nemzetközi társadalom biztonságérzete nem növekedett, a világ a várakozások ellenére nem lett biztonságosabb. A hatalmi erôviszonyok katonai eleme geostratégiai szempontból visszaszorult. Színre léptek azonban a kialakulóban lévô nemzetközi rend működését veszélyeztető destabilizáló erôszak globálissá váló olyan új tényezői, mint a terrorizmus, az aszimmetrikus, degenerációs és identitás háborúk, a népvándorlás jellegét öltő migrációs mozgások, a drogkereskedelem, a járványok elterjedése, korábban leküzdöttnek hitt betegségek ismételt megjelenése, a 
gazdasági-társadalmi elmaradottságból, leszakadásból, valamint az etnikai konfliktusokból származó, egyre aggasztóbbá váló államkudarcok, az emberiség létét fenyegető környezeti károsodások. A nemzetközi rendszer szereplőinek száma megsokszorozódott, diffúzzá vált. A civilizációk és identitások között kiéleződtek a hagyományos és új keletű ellentétek. Mindeközben felerősödött egymáshoz kapcsolódásuk. Ez a körülmény elméletileg oldja a kultúrák közötti összecsapás és küzdelem élességét. Mindez a világrend átalakulásához, a hatalmi befolyásolás, hatalmi befolyás, a geopolitikai kódok és geopolitikai legitimáció szükségszerű felerősödéséhez, a soft power előtérbe kerüléséhez vezet. (KISSINGER, 2015, p. 9-19. és 369-383; SZILÁGYI, 2018, p. 315-334)

A hatalom puha dimenzióinak előtérbe kerülése és a világban végbemenő kommunikációs forradalom ellenére a geopolitikai gondolkodásban a hangsúlyok valójában a gazdasági és az azzal összefüggő területekre, a geoökonómiára, valamint az idó, tér, politika megváltozott szerkez̨etének, viszonyának, jellegzetességeinek, a politika konkrét területtől való egyre nagyobb függetlenedésének, elszakadásának a vizsgálatára irányulnak.

Pascal Lorot tanulmányában a geopolitika és a gazdaság összekapcsolódása és viszonyának megváltozása miatt már egy új korszak kezdetéről ír: „a nemzetek gazdasági érdekei olvashatjuk - felülírják politikai érdekeiket és ez egy új éra, a geoökonomia kezdetét jelenti.” (LOROT, 1997, p. 23-24). Parag Khanna a korábbi értelmezések kiterjesztésével a geopolitika és a globalizáció egységéről, azonosságáról értekezik. „A geopolitika a hatalom és a tér viszonyával foglalkozik. - írja. A globalizáció a mindent átszövő kölcsönös csere következtében a világ népei között egyre szélesebbé és mélyebbé váló kapcsolatokra vonatkozik. A globalizáció és a geopolitika olyan intenzívvé váltak, hogy egy ponton ugyanannak a jelenségnek két oldalát jelentik." 28 (KHANNA, 2008, p. 23-24). A vázolt bonyolult és komplex viszonyrendszer koordinátái között a többközpontú világ egyedüli szuperhatalma számára, korlátozott kapacitása és mozgástere miatt a huszonegyedik században a nemzetközi problémák megoldásának útját a kollektív és humanitárius intervencionalizmus jelenti. Ezt nem csupán Henry Kissinger, de az Egyesült Államok politikai vezetésének döntő többsége is hangsúlyozza.

\section{Oroszország és a neoerurázsionista hatalmi törekvések színre lépése}

2000 márciusában jelentős változsok következtek be az Eurázsia magtérségét alkotó Oroszországban és a Független Államok Közösségében. Az elnökválasztáson győzelmet aratott az orosz birodalmi gondolat és nagyhatalmi eszme határozott programmal rendelkező képviselője, Vlagyimir Putyin, aki külpolitikája elméleti megalapozásában támaszkodott az 1990-es évek második felében Moszkvában színre lépó neoeurázsianista geopolitikai iskola birodalomépítő gondolati rendszerére, amelynek legjelesebb és nemzetközileg legismertebb képviselője és továbbfejlesztője Alekszandr Dugin volt.

A továbbiakban a Dugin által felvázolt modell Oroszország történelmi hivatásával, birodalmi törekvéseivel kapcsolatos elemzéseit tekintjük át legfontosabb művei - a Geopolitika alapjai, a Geopolitika és a nemzetközi viszonyok, a Geopolitika, az Oroszország geopolitikája és más írásai alapján. 
Alexander Dugin egyik legfontosabb műve A geopolitika alapjai (Osznovi geopolityiki) címú könyv, amely 1997-ben, 2000-ben, újabb kiadása 2002-ben jelent meg. (DUGIN, 2000) A monográfia a bevezető fejezetet követő hét fő részből és egy glosszáriumból áll. Elemzésünk a 2000- es kiadás alapján készült, de figyelembe vettük a 2014-ben megjelent és már többször idézett Oroszország geopolitikája (Geopolityika Rossziji) címú könyvet is. (DUGIN, 2014) A 2000-ben publikált múből magyar nyelven részletek olvashatók az Oroszország és Európa című 2004-ben megjelent kötetben. (OROSZORSZÁG ÉS EURÓPA, 2004)

Dugin az Oroszország geopolitikája (DUGIN, 2014) és 2015-ben az Egyesült Királyságban megjelent, A világsziget utolsó háborúja (DUGIN, 2015) címú könyveiben elsősorban történelmi szempontú elemzésekkel tovább bővítette és elmélyítette az elemzésünk alapjául szolgáló monográfiában kifejtett nézetrendszerét.

Dugin A geopolitika alapjai 2000-ben megjelent múve bevezetőjében a geopolitika meghatározásával, a szárazföldi és a tengeri hatalom, a civilizációk, a Magterület és a Rimland kérdéskörével foglalkozik. Az első részben a geopolitika alapító atyáinak, a másodikban a jelenkori geopolitikai elméletek és iskolák képviselőinek munkásságát tekinti át. A harmadik, negyedik és ötödik részt Oroszországgal kapcsolatos geopolitikai problémák vizsgálatának szenteli. A hatodik rész tárgyát az eurázsiai viszonyok értelmezése képezi. Elemzéseinkben ezeknek a fejezeteknek a megállapításaira koncentrálunk. A hetedik részben a szerző a geopolitikai gondolkodás klasszikusainak munkáiból közöl részleteket.

Ami Oroszország helyzetét és a nemzetközi viszonyok alakulását illeti, Dugin könyve második része második fejezetében a mai atlantizmusról írva leszögezi: „A Varsói Szerződés és a Szovjetunió felbomlása annak az atlanti stratégiai irányvonalnak a diadala, amely végig kísérte az egész huszadik századot. A Nyugat győz a Kelettel vívott hidegháborúban. A tengeri hatalom (Sea Power) győzelmet ül a magterület (Heartland) felett.” (DUGIN, 2000, p. 108) A hatalmas területi kiterjedésű eurázsiai szárazföldi birodalmat az Egyesült Államok vezette tengeri hatalom és szövetségesei a Spykmani Rimland (peremövezet) megszervezésével és csatasorba állításával, Anaconda- gyűrűjének szorításával fojtogatták. Ebből a Szovjetunió nem tudott kitörni. A Kelet-Közép-Európából való kivonulás területi engedményére sem volt hajlandó, így nem bírván a ránehezedő nyomást, összeomlott. Ez a bipoláris világ végét, az egypólusú nemzetközi rendszer kezdetét jelentette. Ebben a képben az Oroszország által megtestesített eurázsiaságnak nincs helye. Ezért az nem békélhet meg a dolgok állásával. Keresnie kell a folyamatok visszafordíthatóságának lehetőségét. Meg kell teremtenie egy új kétpólusosság kialakításának feltételrendszerét. Azonban az „eurázsiai kontinentális blokk nem lehet a Varsói Szerződés puszta feltámasztása... Az új kontinentális szövetségnek vagy egész Európát magába kell foglalnia az Atlanti-óceánig, valamint Eurázsia déli partvidékének néhány fontos szektorát - Indiát, Iránt, Indokínát stb., vagy biztosítani kell ezeknek a térségeknek a baráti semlegességét, azaz ki kell vonni óket az atlantizmus kontrollja alól.” (DUGIN, 2000, p. 162) - fogalmaz Dugin. Ez egyben azt is jelenti, hogy újra meg kell határozni Oroszország viszonyát a négy szomszédos civilizációhoz. Nyugaton a latin-germánhoz, Keleten az iszlámhoz, a hinduhoz és a kínaihoz. A szilárd vonatkoztatási 
pont kialakításához azonban szükség van Oroszország szellemi önmeghatározására, és önmagára találására is. „Először is Oroszország lényege, szellemi önmeghatározása identitása kultúrtörténetileg kétségtelenül ...a sem Kelet, sem Nyugat, vagy sem Európa, sem Ázsia, hanem Eurázsia formulával határozható meg... Ezen a síkon Oroszország alapvető érdeke egyediségének bármi áron való megőrzése, eredetiségének megóvása a nyugat kultúrájának és a Kelet tradícióinak kihívásával szemben.” (DUGIN, 2000, p. 167) Geostratégiailag ez a peremterületek szövetségessé tételét, a partvidéki zónákba történő benyomulást, a Rimland legnagyobb része semlegességének biztosítását, az orosz birodalomépítés folyamatának felerősítését, és ennek szerves részeként a meleg tengerekhez való kijutást, a Sea Power és a Heartland Eurázsiai szövetségi rendszerben történő egyesítését jelenti.

Az új szövetségi rendszernek egyesítenie kell az atlantizmust megtestesító, amerikai vezetésú Gazdag Nyugat elleni küzdelemben Oroszország-Eurázsiát és a Szegény Dél- Harmadik világát.

Más megközelítésben az Amerikával a középpontjában álló három nagy térség, Észak-és DélAmerika, Európa és Ázsia Oroszország-Eurázsia ellen irányuló stratégiai szövetségének Amerika-ellenes rendszerré kell alakulnia

Ennek a célnak és stratégiának a megvalósítása érdekében Az Eurázsia tengelyét alkotó pravoszláv civilizáció országainak az Európa tengelyét képező Közép-Európa államaival és az antikontinentális erők valószínűsíthető szövetségesének tekinthető európai Nyugat országaival újra kell osztaniuk egymás között a befolyási övezeteket a mackinderi értelemben vett Kelet-Európában Németország és Oroszország között.

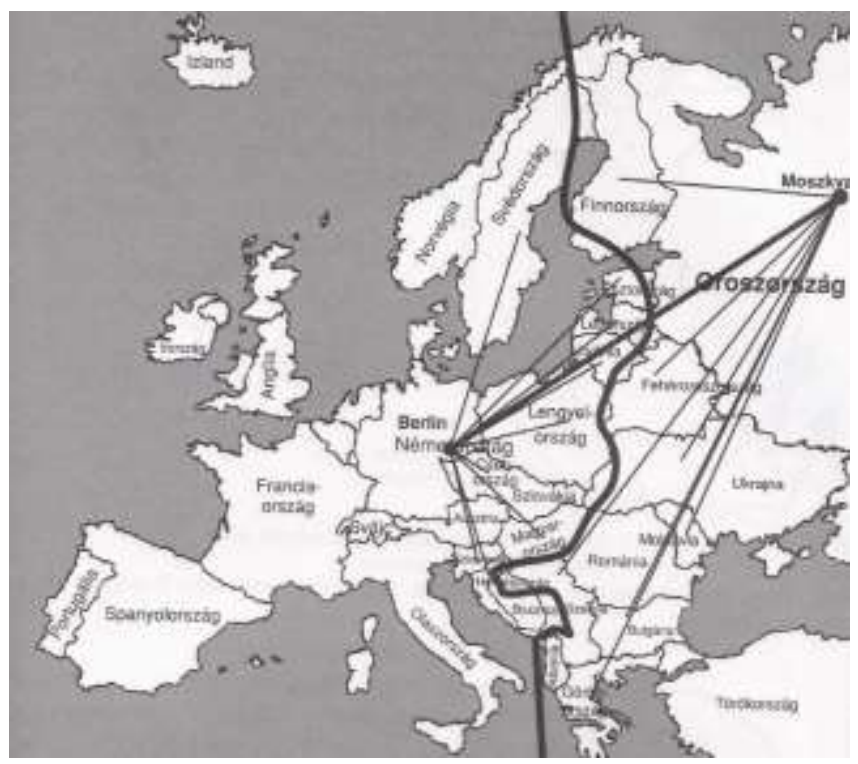

5. ábra. A befolyási övezetek újraosztása Kelet-Európában

Forrás: DUGIN, A. (2000): Osz̧novi geopolityiki. Arktogeia, Mosžkva. p. 227

A folyamat sikere esetén Dugin egy Karl Ernst Haushofer pánrégió felfogásával rokonságot mutató négypólusú multipoláris világ modelljét vázolja fel. 
Ennek a többpólusú nemzetközi rendszernek a Moszkva-Berlin, Moszkva-Teherán, Moszkva-Tokió és - a Sanghaji Együttmúködési Szervezetet is figyelembe véve - MoszkvaPeking szövetségi tengely mentén kell megvalósulnia.

Oroszországnak Dugin felfogása szerint nincs választása. „Az Orosz Föderációnak nincs államtörténete, határai esetlegesek, kulturális irányjelzői zavarosak, politikai rendszere ingatag és képlékeny, etnikai térképe vegyes, gazdasági struktúrája széttöredezett és részben szétesett. Az adott konglomerátum csak a globálisabb geopolitikai alakulat bomlásának a terméke, a teljes képből kiszakított részlet.

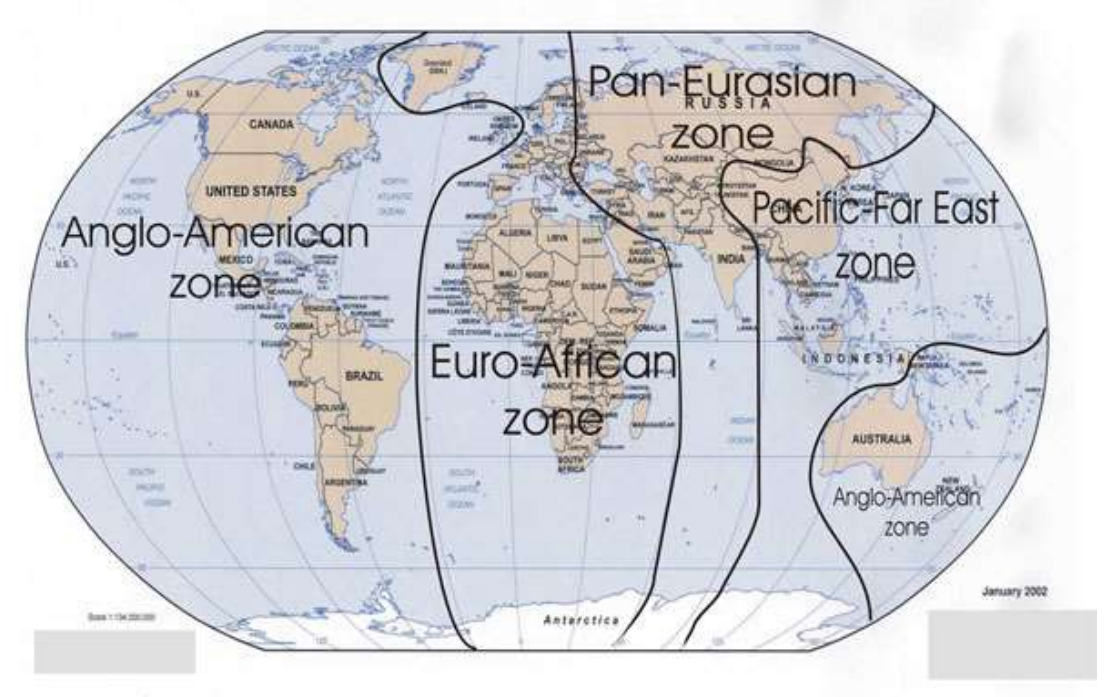

Map of multipolar world. Four zones - four poles

6. ábra. A négypólusú multipoláris világ

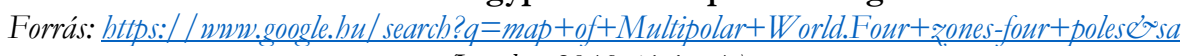
(Letöltve:2019. június 1.)

Ha az Orosz Föderáció nem az orosz állam, akkor a FÁK sem az.” (DUGIN, 2000, p. 184) Dugin álláspontja szerint Oroszország nem eshet a regionális hatalmiság csapdájába. Az a státusz az orosz nemzet számára egyenlő az öngyilkossággal. „Oroszország elképzelhetetlen birodalom nélkül.” (DUGIN, 2000, p. 193) - hangsúlyozza. Ebben a keretben kell tehát értelmeznünk a 2014 tavasza óta kirobban ukrán konfliktust is. Az ország létének Dugin szerint nincs perspektívája, specifikus sajátosságok sem támasztják alá szuverenitását és létezésének fontosságát.

Oroszország és az Orosz Föderáció nagyhatalmi-birodalmi státusza tehát a többpólusú világ kialakulásához vezető Eurázsiai Unió (EaU), Jevrazijszkij Szojuz (JESZ) létrehozásától függ.

„Minden egyes történelmi kornak megvan a maga politikai, ideológiai, gazdasági és kulturális koordináta rendszere. - írja Az Eurázsiai nézőpont címú tanulmányában. (DUGIN, 2012, p. 348) - „Például a XIX. század Oroszországban a „,szlavofilok” „zapadnyikok” ellen vívott küzdelme jegyében telt el. A XX. században a „,vörösek” és a „fehérek” közötti 
szembenállásnak lehettünk tanúi. A XXI. században pedig az atlantisták (az egypólusú globalizmus hívei) és az eurázsianisták közötti ellentétek dominálnak.

Az atlantista világrend és globalizáció állításaival szemben fellépnek a többpólusú világ hívei- ők az eurázsianisták." (DUGIN, 2012, p. 348-349)

A nemzetközi rendszer két szembenálló alternatívája, erőközpontja két egymástól eltérő felfogást, intézményi megoldást, intézményrendszert, berendezkedést és jövőképet képvisel, állítja Dugin.

„Az eurázsiai felfogás képviselői következetesen a többpólusosság elvét vallják, s fellépnek az atlantistákhoz kapcsolódó egypólusú globalizáció ellen. Ezen új világ pólusainak minőségében nem a hagyományos értelemben vett államok, hanem új, integrált civilizációs formák („,nagy térségek”) jelennek meg, amelyek geoökonómiai övezetekké (geoökonómiai zónák) egyesülnek." (DUGIN, 2012, p. 350). A 6. ábra (térkép) segítségével megjelenített nagyrégiók, szuperhatalmak által uralt befolyási övezetek megszervezése és nemzetközi legitimációja esetén a világban kevésbé valószínűek a globális konfliktusok, a véres háborúk és az emberiség létét fenyegető összeütközések.

Oroszország és eurázsaiai kontinentális övezetbeli partnerei harmonikus kapcsolatra törekednek szomszédjaikkal és szemben állnak az atlantisták globális terveivel, amelyek célja a Nyugat oligarchikus struktúrájának ellenôrzése alatt egy egypólusú sztereotipizált világ megszervezése.

A befolyási övezetek vázolt nagytérségi összefüggés rendszerében ugyanakkor Dugin a kisés közepes nagyságú államok nemzeti szintű szerveződéseinek, a nemzeti és a nemzeti kisebbséggel kapcsolatos kérdéseknek nem tulajdonít jelentőséget. Azok problémái feloldódnak és megoldódnak az új geopolitikai rend Németország és Oroszország által ellenőrzött és birodalmi kereteiben. (DUGIN, 2000, p. 297-385)

Az atlantizmus és az USA vezérelt globalizmus elleni küzdelemben Dugin (és az orosz vezetés) szerint központi szerepet játszik az Eurázsia Gazdasági Unió létrehozása. Milyennek kell lennie ennek a szerveződésnek, arra a választ a Dugin által szerkesztett kötetben Jurij Szolozobov tanulmányából tudhatjuk meg." Az Eurázsiai Unió: elmélettôl a gyakorlatig” címet viselő elemzés részletesen bemutatja a szervezet keletkezéstörtének főbb állomásait és jellegzetességeit.

Az Eurázsiai Unió (Jevrazijszkij Szojuz) létrehozására a kazah elnök, Nurszultán Nazarbajev tett javaslatot 1994-ben. Ebben a FÁK országai számára elengedhetetlen szükségszerűségnek nevezte egy az Európai Unióhoz hasonló szövetségi rendszer megteremtését. Véleménye szerint azonban ennek az integrációnak különböznie is kell az EU-tól annyiban, hogy annak létrehozása nem sértheti a résztvevő államok jogegyenlőségét. Az együttműködésnek a politikai szuverenitás feladása nélkül kell megvalósulnia. Elsősorban a gazdasági együttműködés elmélyítését kell szolgálnia, de szavatolnia kell a résztvevő államok kollektív biztonságát is.

A FÁK létrejöttétől azonban hosszú és nehéz út vezetett a 2015. január elsején megalakult Eurázsiai Gazdasági Unióig. Az integráció fejlődésére Putyin 2000-es hatalomra kerülése adta a döntő lökést. 
2000. október 10-én Asztanába létrejött az Eurázsiaia Gazdasági Közösség, a JEVRAZESZ (Jevroaziatszkoje Ekonomicseszkoje Szoobscsesztvo). A gazdasági integrációban öt ország vesz részt. Oroszország mellett Belorusszia, Kazahsztán, Kirgizisztán és Tádzsikisztán tagja a szervezetnek. Érdemi előrelépést jelentett a szervezet életében a gazdaság-és a pénzpolitika területén követendő célok megfogalmazása, az 1990-es években létrehozott Vámunió megerősödése, valamint a Független Államok Közössége keretei között megvalósuló energetikai, infrastrukturális és gazdasági együttmúködés. A szervezet a volt Szovjetunió gazdasági potenciáljának 85\%-át képviseli. A szervezet jövőjével kapcsolatban Nurszultán Nazarbajev 2011.november 18-án adott interjújában kijelentette, hogy az a hasonló típusú integrációkra jellemző klasszikus utat járja végig. Az első lépést a közös kereskedelmi övezet létrehozása jelenti. A másodikat a vámszövetség, a harmadikat az egységes gazdasági térség, a negyediket a gazdasági unió, az ötödiket a közös valuta bevezetése követi. (NAZARBAJEV, 2011)

Az Eurázsia Gazdasági Unió 2015-ös hivatalos megalakulása ennek a modellnek az negyedik fázisát képviseli.

Összességében azt mondhatjuk, hogy Nazarbajev egy sajátos, sui generis jellegű birodalmi föderáció megteremtésének a híve, amely számos hasonlóságot mutat az 1991 december 25 e előtti struktúrákkal. Ezért különösen fontosnak tartja hangsúlyozni, hogy „Nincs szó a Szovjetunió semmiféle restaurációjáról vagy reinkarnációjáról. Az nem lehetséges.... ...amire szükség van az egy jövőre irányuló pragmatikus megközelítés.” (SZOLOZOBOV, 2012, p. 372)

Vlagyimir Putyin orosz elnök az Eurázsiai Gazdasági Unió kapcsán az ázsiai, a Csendesóceáni, az európai és a latin-amerikai térség összekapcsolását emeli ki. Ez az EaEu, az Ázsiai és Csendes-óceáni Gazdasági Együttműködési szervezet, az APEC, a dél-amerikai államok szabadkereskedelmi integrációs szervezete, a Mercosur és az Európai Unió között megvalósuló, az USA által vezetett atlanti világgal szemben kialakítandó kooperációt jelenti.

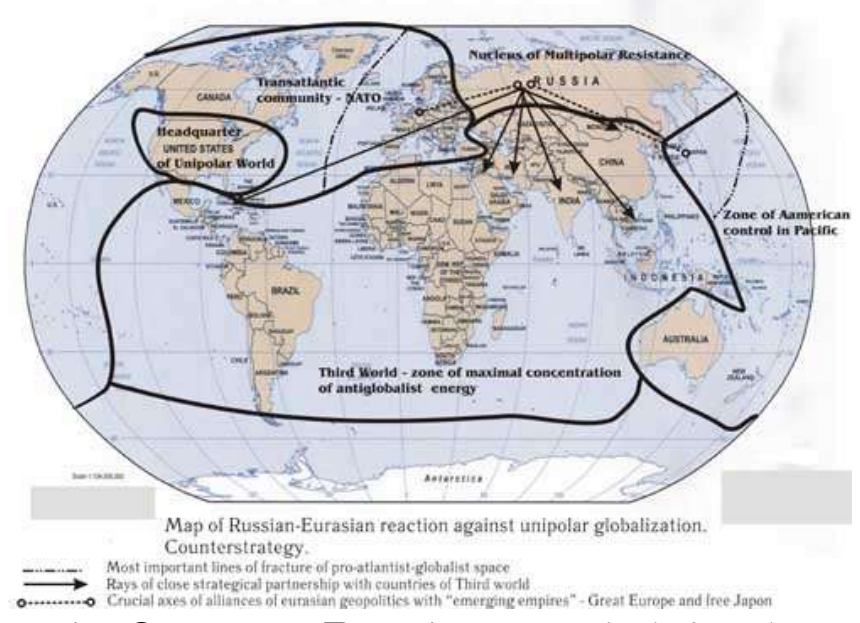

7. ábra. Oroszország-Eurázsia együttmüködési rendszere

Forrás: DUGIN, A (2013): Multipolarism as an Open Project. Journal of Eurasian Affairs. Volume 1.p. 9 
Oroszország és a posztszovjet térség - szögezi le Szolozobov- a globalizáció viszonyai között két út között választhat.” Az első - Kínához vagy az EU-hoz történő félperifériális jellegű integráció... A második - saját erőforrások alapján Eurázsia közepén létrehozni az Eurázsiai Uniót." (SZOLOZOBOV, 2012, p. 373)

Az orosz birodalmi gondolat harcosa és teoretikusa, Alekszandr Dugin úgy véli, hogy „Előbb vagy utóbb a nagy beteljesülések és drámai csaták után üt Eurázsia órája.” (DUGIN, 2012, p. 360)

Ahhoz azonban, hogy az orosz geopolitikai gondolkodás sajátosságait megértsük, állítja Dugin, tudomásul kell vennünk, hogy ,az orosz geopolitika nem egyszerúen az egyetemes geopolitikai törvényszerűségek jól definiált konkrét körülményekre történő alkalmazását jelenti. A probléma abban áll, hogy az orosz geopolitikát csak az orosz társadalom jellegzetességeinek mély megértése, a jelennek és a múltnak az együttes tanulmányozása alapján lehet vizsgálni... A problémát nem egyszerúen az orosz területek (jelenkori és történeti) földrajzi struktúrája jelenti; ez fontos, de nem elégséges. Tisztáznunk kell azt is, hogy az orosz társadalom hogyan érti és értelmezi e területek szerkezetének alakulását a különböző időszakokban; mit jelent a „saját” és mit a „más”fogalma, hogyan fogja fel a határok, a kultúra,a civilizáció és identitás, valamint a szomszédos területek változása következtében a viszonyt az etnosz és a nép között....További nyitott kérdésként merül fel az orosz társadalom kormányzati formák típusaival kapcsolatos attitűdje ...nekünk kell az orosz történelem új társadalompolitikai modelljét kiépíteni.” (DUGIN, 2015, p. 1-2). Dugin szerint meg kell találni az egyes történelmi szakaszokra jellemző sajátosságokat és fel kell tárni az orosz kultúra jellegzetességeit. Eközben azt is hangsúlyozza, hogy a geopolitikai rendszerrel kapcsolatos pozíció függ a megfigyelő, vagy elemző értelmezésétől. Ez csak akkor lehet eredményes, ha a szubjektív és objektív tényezők egységes szerkezetbe rendeződnek. Véleménye szerint „...az orosz geopolitika a Heartland geopolitikája; szárazföldi bázison alapuló geopolitika, a szárazföld geopolitikája.” (DUGIN, 2015, p. 5). A tizenötödik század óta a Oroszország a „szárazföldi civilizáció”, a kontinentális Róma pólusát testesíti meg. Erre a civilizációra a konzervativizmus, a holisztikus szemléletmód, az antropológiai közösség (a nép fontosabb, mint az egyén), az áldozatvállalás, az idealisztikus irányultság, a hűség, az aszkétizmus, a becsületesség és a lojalitás a jellemző. A kétpólusú, hidegháborús világban „Geopolitikailag ... egyensúly állt fenn a globális jellegű thallaszokratikus kapitalista Nyugat és messze az SZSZSZR határain túlterjeszkedő tellurokratikus kommunista Kelet között.” (DUGIN, 2015, p. 42). A többpólusú, és interdependens nemzetközi viszonyrendszer keretei között ezen állapot ismételt megteremtésének szolgálatát vállalta az orosz geopolitika és kormányzati külpolitika.

\section{Kína ante portas- avagy a többpólusú nemzetközi rendszer bizonytalan körvonalai}

Történelmi tény. hogy Moszkva - BRICS országok tagjaként - hatalmát újjászervezve, politikai szuverenitását a Szovjetunió által elveszett területek egy részére kiterjesztve birodalmi politizálásba kezdett. Az orosz kormányzat az Eurazsianizmus, és a nemzetközi rendszer multipolárissá alakítása stratégiájának irányvonalát képviseli és érvényesíti 
külpolitikájában. Az Eurázsiai Gazdasági Unió meghirdetésével és létrehozásával, a Sanghaji Együttmúködési Szervezet megteremtésével, az Ázsiai és Csendes-óceáni Gazdasági Együttmúködéshez történő csatlakozással és más nemzetközi integrációkkal való kapcsolatok kiépítésével a nemzetközi viszonyok rendszerének struktúraképző nagyhatalma, világgazdasági értelemben véve ,független periféria” lett, amelynek törekvéseit több tényező korlátozza és befolyásolja.

Korlátozza egyrészt az Amerikai Egyesült Államok szuperhatalmi státusza és poziciója. Keretek közé szorítja másfelől az Eurázsiai térségben egyre jelentősebb szerepet játszó, globális nagyhatalommá váló Kína. Peking nem csupán a Sanghaji Együttmúködési Szervezet és az Ázsiai Együttműködési Fórum révén terjesztette ki és növelte befolyását az Eurázsiai térségben. A kínai vezetés 2013-ban meghírdette a világhatalmi befolyásának növelését és érvényesítését szolgáló Új Selyemút Gazdasági Övezet koncepciót és azt egyre következetesebben és egyre határozottabban érvényesíti is. (PÉTI, 2017).

A földrajzilag és gazdaságilag Kelet- Közép Európát is magában foglaló stratégiában nagy szerepet kap a szárazföldi és a vízi új Selyemút, amelyet kiegészít az Északi-sarkon át vezető, azt megkerülő már tesztelt útvonal is.

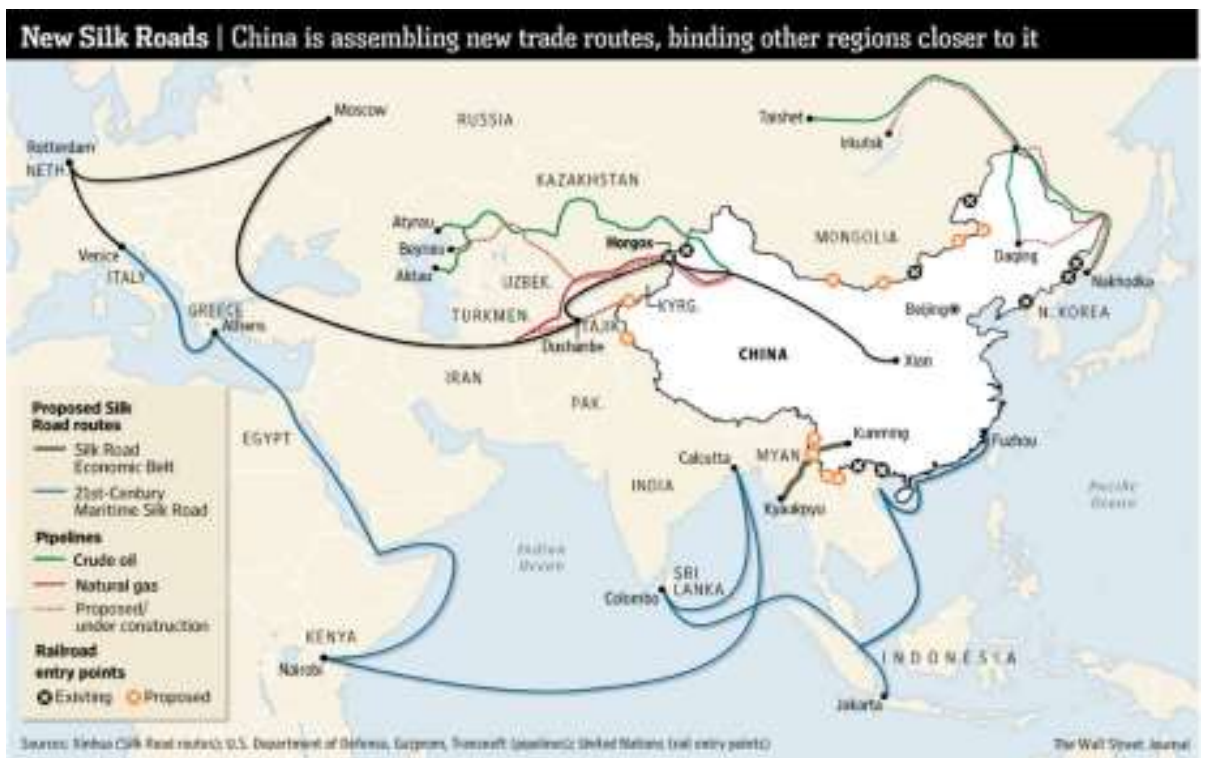

8. ábra. A szárazföldi és tengeri Új Selyemút

Forrás: : http:// wmm. silkroutes.net/OBOR/9MapWallStreetJounal.jpg (Letöltve:2019. július 5.) 


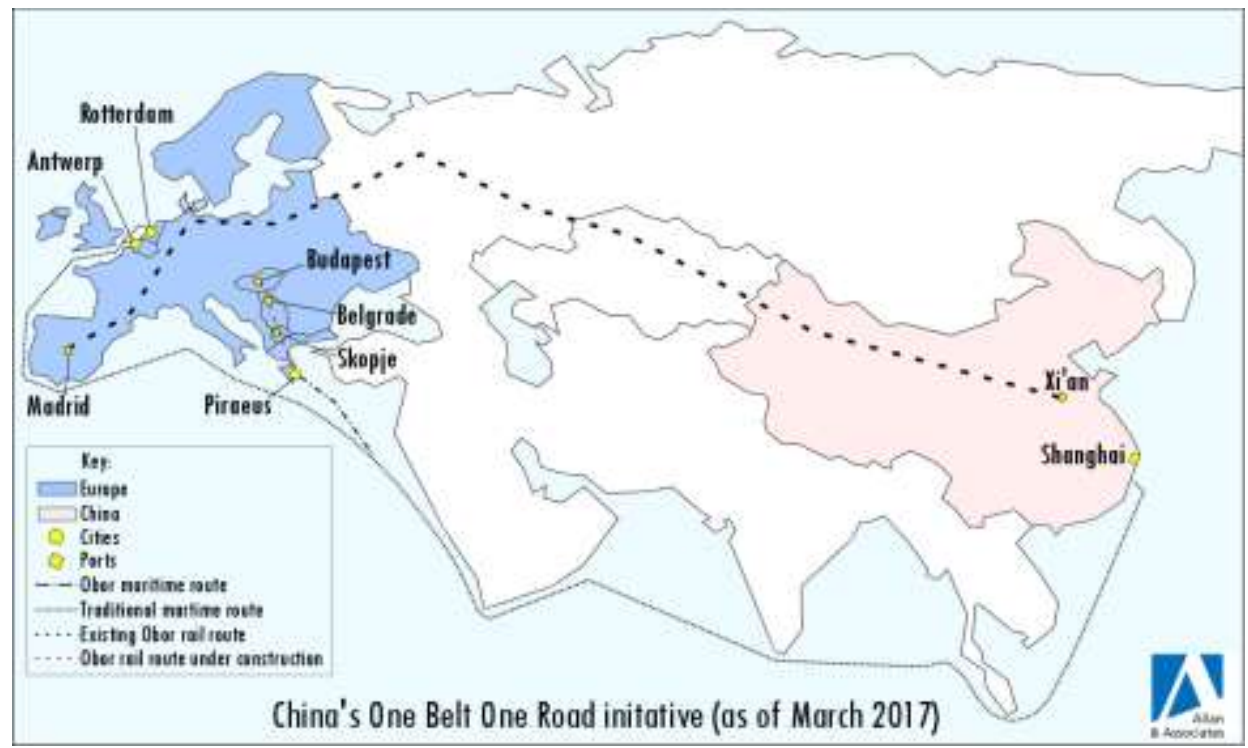

9. ábra. az Egy Övezet Egy Út Kezdeményezés állomásai

Forrás:bttps:/ / www.a2globalrisk.com/analysis/asia-pacific/chinas-one-belt-one-road-bits-road-bump-in-bungary/ (Letöltés:2019. július 1.)

A kínai világhatalmi tervek érvényesítésé szolgáló Egy Övezet, Egy Út, avagy Pekingben az utóbbi időkben a Belt and Road Initiative-nak nevezett koncepció fontos eszközének, elemének számít a térségi befektetések céljat szolgáló Ázsiai Befektetési Bank kliens hálózatának tervezett és folyamatban lévő kialakítása is.

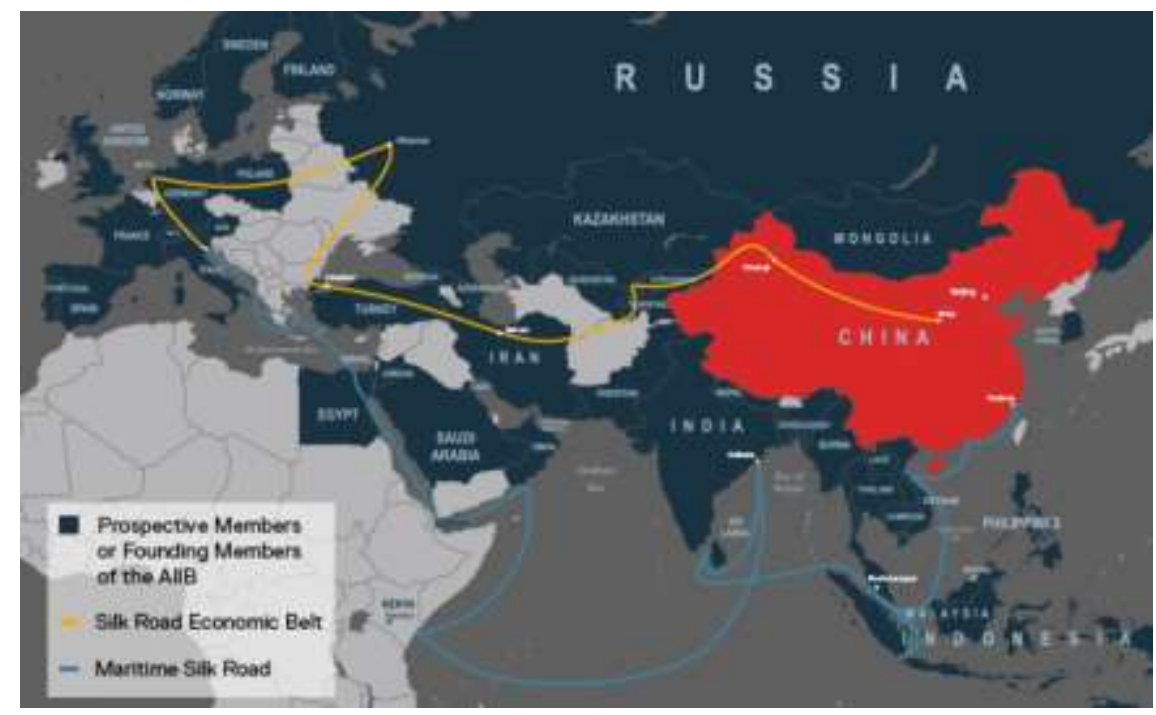

10. ábra. Az Egy Övezet Egy Út és az Ázsiai Infrastrukturális Befektetési Bank

Forrás: http:/ / theciarticle/ evaluating-chinas-new-silk-road (Letöltés:2019. július 20.) 
A számok és a nemzetközi gazdaságstatisztikai adatok is Kína előretöréséről tanúskodnak. A Világbank által 2015-ben készített és a Világgazdasági Fórum 2017-ben aktualizált és felülvizsgált összeállítása szerint a világ legnagyobb gazdaságai sorában az előúllított GDP abszolút nagysága tekintetében az első három helyet az Egyesült Államok (24,3\%), Kína $(14,8 \%)$ és Japán $(5,9 \%)$ foglalja el. Hatalmas a különbség azonban az első két helyezett ország, az USA, valamint Kína és Japán, továbbá a negyedik Németország (4,5\%) gazdasági ereje és befolyása között. Ebben a sorban Oroszország a világ GDP-jéből Olaszországgal és Brazíliával megegyezô módon csupán 1,8\%-ban részesedik.

\section{The world's biggest economies}

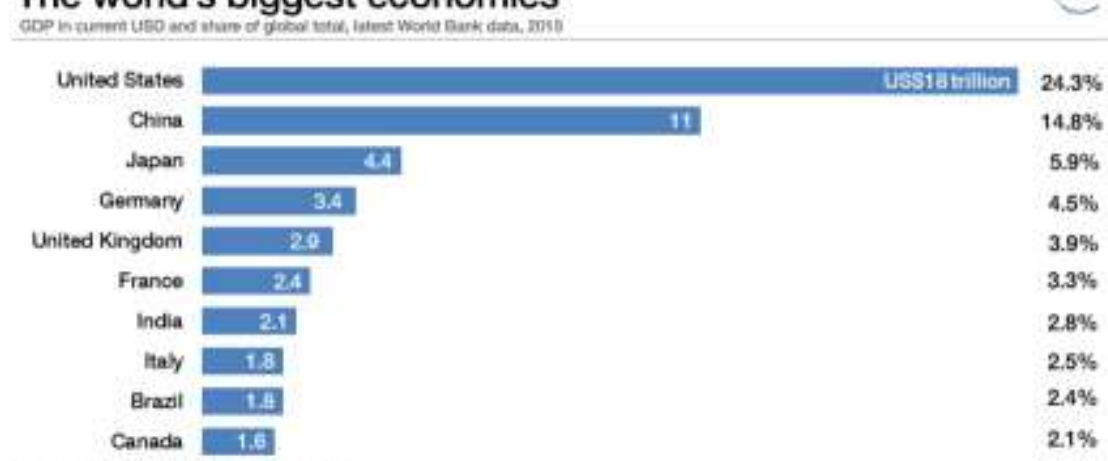

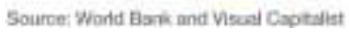

\section{1. ábra. A legnagyobb gazdaságai 2017- ben}

Forrás:bttps:/ / es.weforum.org/agenda/2017/03/las-10-mayores-economias-del-mundo-en-2017

A trendek egyértelműen Ázsia, elsősorban Kína és India gazdasági előretörésről és megerősödésérôl, a nemzetközi viszonyok rendszere erősorrendjének és befolyási övezeteinek átalakulásáról, megváltozásáról szólnak.

Projected GDP Ranking 2030

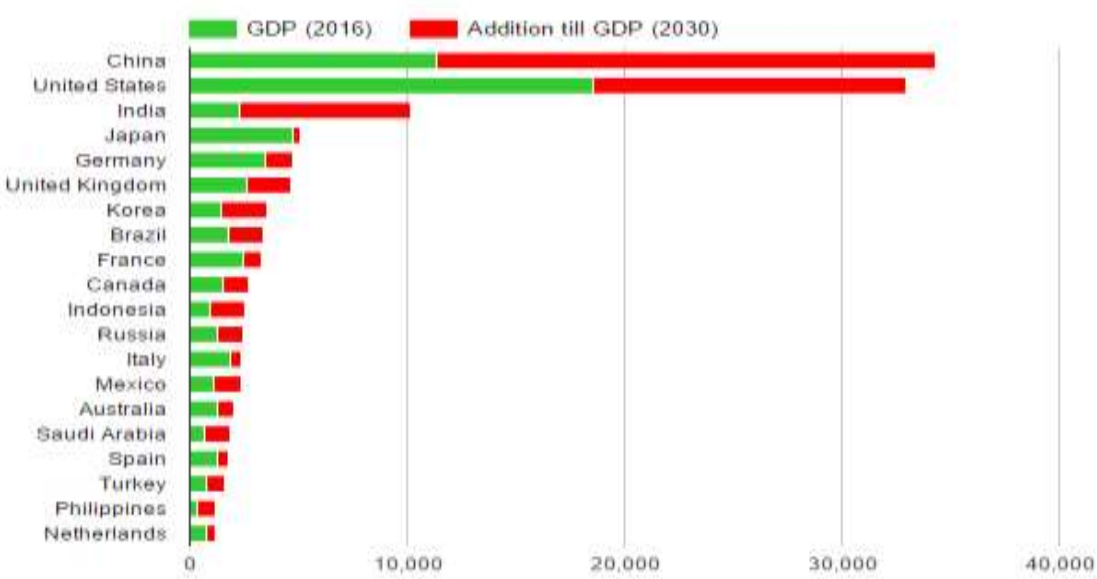

12. ábra. 2030-ra vonatkozó globális GDP előrejelzés

Forrás 11.: European Commission (2016): Projected GDP ranking 2030. 
Igen jelentős gazdasági átrendeződést prognosztizálnak az Európai Bizottság 2030-ra vonatkozó előrejelzései is. Ennek adatai szerint az említett időpontra mind a GDP növekedési ütemét, mind abszolút értékét tekintve Kína kerül az első helyre, megelő́zve az Egyesült Államokat. India feljön a harmadik helyre. Oroszországot sorrendben Korea, Brazília, Kanada és Indonézia is megelőzi. Mindezek a tényezők, a prognosztizált és feltételezett változások jelentős hatást gyakorolnak Kelet- Közép-Európa gazdasági fejlődésére. Növelik a térség és benne Magyarország többpólusú nemzetközi rendszerben történő relatív mozgásterét.

Ez utóbbi kérdéskör vizsgálata és részletes elemzése azonban meghaladja e tanulmány kereteit és túlmutat a geostratégiai modellek történeti változásainak ábrázolásán. Részletes vizsgálata további kutatásokat és önálló feldolgozást igényel.

\section{FELHASZNÁLT IRODALOM}

AGUIAR, J (2000): Modelos de Globalização. In: O Interesse Nacional e a Globalização. Edições Cosmos, Instituto da Defesa Nacional, Lisboa, 2000.

ALDENUEVA, A. J. (2001): Globalización: concepto y papel del Estado. Boletín de la Facultad de Derecho (UNED), 2001. 18. sz.

AXFORD, B. and HUGGINS, R. (1999): Towards a post-national polity: the emergence of Network Society in Europe. In.: Whose Europe? The turn towards Democracy. Edited by Dennis Smith and Sue Wright. Blackwell Publishers, Oxford.

BRZEZINSKI, Z. (1999): A nagy sakktábla. Európa Kiadó, Budapest.

BREZINSKI, Z. (2013): Stratégiai vízió. Amerika és a globális hatalom válsága. Antall József Tudásközpont. Budapest.

CASTELLS, M. (2005): A hálózati társadalom kialakulása. Gondolat-Infonia, Budapest.

CHASE, R.-HILL, E.- KENNEDY, P. (1996): Estados axiales y estraegía de Estados Unidos. Política Exterior. no.50. p.83-102.

COHEN, S. B. (2009): Geopolitics. The Geography of International Relations. Rowman \& Littlefield Publishers, Inc. New York.

DUGIN, A. (2000): Osznovi geopolityiki. Arktogeia, Moszkva.

DUGIN, A. (2004): Projekt „Eurazija.” EKCMO, Jauza, Moszkva.

DUGIN, A. (2012): The Fourth Political Theory. Arktos Media Ltd. London.

DUGIN, A. (red) (2012): Geopolityika i mezsdunarodnije otnosenyija. Jevrazijszkoje Dvizsenyije. Moszkva.

DUGIN, A. (2013): Multipolarism as an Open Project. Journal of Eurasian Affairs.Volume 1.p.5-15.

DUGIN, A. (2014): Geopolityika Rossziji. Akagyemicsevszkij Projekt. Moszkva.

DUGIN, A. (2015): Last War of the World-Island. The Geopolitics of Contemporary Russia. Arktos Media Ltd. London.

DUGIN, A. (2015): Geopolityika. Akagyemicsevszkij Projekt. Moszkva. 
DUGIN Alexander on Eurasianism, the Geopolitics of Land and Sea, and a Russian Theory of Multipolarity.http://www.theory-talks.org/2014/12/theory-talk-66.html.es

http://www.isn.ethz.ch/Digital-Library/Articles/Detail/?id=186525.

HELD, D. (2000): A globalizing world? Culture, economics, politic. In.: Global Democracy: key debates. Ed. Barry Holden, London.

HUNTINGTON, S. (1998): A civilizációk összecsapása és a világrend átalakulása. Európa Kiadó, Budapest.

KHANNA, P. (2008): The Second World. Empire and Influence in the New Order. Random House, New York.

KISSINGER, H. (2002): Korszakváltás az amerikai külpolitikában? A 21. századi Amerika diplomáciai kérdései. Panem-Grafo, Budapest.

KISSINGER, H. (2008): Diplomácia. Panem Könyvkiadó, Budapest.

KISSINGER, H. (2015): Világrend. Antall József Tudásközpont, Budapest

LOROT, P. (1997): De la géopolitique a la géoéconomie. Revue Française de Géoéconomie, 1997. no.1.p.9-19.

LOUREIRO DOS SANTOS, J. A. (2008), O Coração da Eurásia contra o resto do mundo. (Ensaio geopolítico e relações internacionais). Comunicação Academia de Ciêcias de Lisboa do socio correspondente. Lisboa.

MAÇÃES, B. (2018): Eurázsia hajnala. Az új geopolitikai világrend nyomában. Pallas Athéné Books. Pallas Athéné Könyvkiadó Kft. Budapest.

NAZARBAJEV, N. (2011): Jevrazijszkij Szojuz: ot igyeji k isztoriji buduscsevo. Izvesztyija, 2011. október 25.(http://www.izvestia.ru/news/504908.). .(http://www.izvestia.ru/news/504908.)

NOGUÉ FONTE, J. y VICENTE RUFI, J. (2001): Geopolítica, identidad y globalización. Editorial Ariel S. A., Barcelona

OROSZORSZÁG ÉS EURÓPA Orosz geopolitikai szöveggyűjtemény. (2004): Szerkesztette: Ljubov Siselina és Gazdag Ferenc (2004). Zrínyi Kiadó, Budapest.

PÉTI, M. (szerkesztette) (2017): Az Új Selyemút Gazdasági Övezet geostratégiai és földrajzi dimenziói. BCE. Budapest.

RAI NAYAR, B. (2005): The Geopolitics of Globalization.The Consequences for Development. Oxford University Press.Oxford.

ROSENAU, J. (1990): Turbulence in World Politics. Princeton University Press, Princeton, New Jersey.

ROSSZIJA I JEVROPA: KRESZTOMATYIJA PO RUSSZKOJ GEOPOLITYIKE. (2007): Szosztavitylej L. N. Siselina. Nauka. Moszkva.

SZILÁGYI, I. (2006): Nemzeti identitás és szuverenitás az Európai Uniós csatlakozás tükrében. In: SZILÁGYI István: Portugália és Spanyolország. Történelem és politika a huszadik században. Veszprémi Humán Tudományokért Alapítvány. Veszprém. 277-292. o.

SZILÁGYI, I. (2018): Geopolitika. Második, bővített kiadás. PAIGEO, Budapest.

SZILÁGYI, I (2019): Az orosz geopolitikai gondolkodás. Áttekintés.Geopolitikai Szemle.2019. 1. sz.p.9-41.

SZOLOZOBOV, J. (2012): Jevrazijszkij Szojuz: ot igyeji k isztoriji buduscsevo. In: Geopolityika i mezsdunarodnije otnosenyija. Jevrazijszkoje Dvizsenyije. Moszkva.p.354-374. 
WALLERNSTEIN, I. (1983): A modern világgazdasági rendszer kialakulása. Gondolat Kiadó, Budapest.

WHOSE EUROPE? THE TURN TOWARD DEMOCRACY. (1999): Edited by Dennis Smith and Sue Wright. Blackwell Publishers, Oxford. 
${ }^{18}$ 这 57
BGE 